\title{
МИкОЛА ГОГОЛЬ: ХРИСТИЯНИн І ФІЛОСОФ
}

\author{
П.Г. Берко, Б.С.Левик
}

$\ll Я$ - пноземеп, забревпий на тужбп-
ну пскать того, что только находится
в одной родине...»

Серед інтелектуалів українського народу Микола Гоголь займає своєрідне місце. Це був письменник всесвітньо відомий, проте водночас - i надзвичайно одинокий. Від його творчості йдуть нові шляхи не тільки в культурі, але і філософії. Філософські впливи не торкнулися його безпосередньо, хоча на становлення його світогляду вагомий вплив справили ідеї гуманізму, особливо романтизму.

Дослідник Шенрок, як біограф Миколи Гоголя, у своїі̆ чотиритомній праці найбільш широко розкрив життя і психіку письменника. Вчений відзначив, що, незважаючи на російський погляд і патріотизм, письменник був «не тільки своїм походженням, але й за складом характеру і своїм зверхнім виглядом справжній малорос; всіма найглибшими й потаємними струнами Душі він був зв'язаний зі своєю поетичною батьківщиною, ніколи не переставав бути правдивим і вірним сином України» $^{1}$.

Зрештою й сам Микола Гоголь $\mathrm{y}$ листах від 2 липня і 9 листопада 1833 року до свого друга Михайла Максимовича пише: «Киньте, справді, Кацапію та їдьте в Гетьманщину. Я сам збираюсь те ж зробить й наступного року накивати звідси. Дурні ми, справді, як поміркувати

${ }^{1}$ Шенрож В. Сочинения. - Берлин: Слово, 1922.-С. 101. 
добренько! Для чого й кому ми жертвуемо всім? Їдьмо! Я беруся за історію нашої єдиної, бідної України» ${ }^{2}$.

А з яким хвилюванням і великою любов'ю пише він Михайлові Максимовичу про Київ: «Вдячний тобі за все: за листа, за роздуми у ньому, за новини і т. ін. Уяви собі, я також думав. Туди, туди! У Київ! У древній, у прекрасний Київ! Він наш, він не їх, неправда? Там або навколо нього, творилися справи давнини нашої... $\gg^{3}$.

Отже, повинні відпасти будь-які сумніви. Українська душа Гоголя промовляе до нас з усіеї його літературної творчості. Як мислитель, він стоїть поруч Григорія Сковороди, з яким має багато спільного. Обидва у житті були диваками, бездомними мандрівниками, без власної сім'ї i дому; мали естетичну вдачу із закохуванням у поезію, пісні, музику. Обидва назовні були то несміливі й мало товариські, з нахилом до самітності, меланхолійні, то щиро веселі, з хистом до сатири, гумору, іронії, вперті у своїх особистих задумах і планах.

Весь творчий доробок Гоголя є единим і цілісним та залишаеться у руслі українського культурного прогресу. Євген Маланюк робить висновок, що «творчість Миколи Гоголя, принаймні для певної верстви нашого народу, була і $\varepsilon$ джерелом певної свідомості, коли й вже не «національної», то етнічної й, що найважливіше, «духовної» ${ }^{4}$. Останне справді «найважливіше». Воно спонукае до погляду на творчість Миколи Гоголя не так з огляду на те, про кого він писав, як зважаючи на те, що він писав, який, власне, світоглядно-духовний фундамент було закладено в його творчій спадщині.

Характерною традицією національної філософії $\mathrm{e}$ «філософія серця», пріоритет «серця» («душі») над «головою», що визначає за основу психічного життя людини не свідомість, не процеси мислення, а ті психічні переживання, що мають надсвідомий характер і позначені терміном «серце», «душа». У зв'язку з цим надзвичайно актуальною є потреба дослідження творчої спадщини тих діячів української культури, які зосередили свою увагу на індивідуальному вимірі буття, на висвітленні екзистенціальної інтимності людської душі. Українські філософи з однаковою легкістю користуються пером філософа, аналізуючи «екзистенціали» людського буття, і пером художника, моделюючи реальні життеві ситуації, в яких виявляються ці абстрактні «екзистенціали»-смерть, страх, сміх, кохання, хвороба, самотність та взаємо-

\footnotetext{
${ }^{2}$ Гоголь Н.В. Собрание сочинений: В 4-х томах. - Москва, 1968. - Т. 4. - С. 228

${ }^{3}$ Taм же. - C. 229 .

${ }^{4}$ Маланюк $Є$. Нарис з історії української культури. - Нью-Йорк, 1954. - С. $7,15$.
} 
нівелюючий вплив людських існувань. Найяскравішим представником цього напряму е Микола Гоголь.

Романтичний досвід завжди складався з антитез та із синтез тривоги і спокою, примирення і протесту - у цій діалектичній грі весь романтизм Гоголя. Всередині романтизму $є$ тільки бажані й неправдиві шляхи, тому релігійний світогляд молодого Гоголя - дещо розпливчастий. Це був не чітко визначений релігійний гуманізм, романтична схвильованість й чутливість, розчуленість, а реалії Церкви мистець відчував лише естетично.

Проте водночас вже з юних літ Миколу Гоголя відрізняв високий рівень самосвідомості. «Ще з самих часів минулих, з самих років майже нерозуміння, - зізнався він, 一я палав незгасною ревністю зробити життя своє потрібним для блага держави, я кипів принести хоча б найменшу користь людству ${ }^{5}$.

Це було щире бажання. I справді, все свое життя мистець намагався підкорити цій благородній меті. Однак важко, здається, вишукати серед історичних осіб більш дисгармонійну постать, ніж ця благородна людина. «Тупий школяр - i геніальний письменник,- пише про нього Сергій Єфремов, - великий гуморист, сміхотун та вигадчик - $\mathrm{i}$ не менший песиміст; визнаний реаліст, батько «натуральної школи» в російському письменстві - i неокраяний містик; прихильник особистого морального самовдосконалення - $\mathrm{i}$ джерело протесту проти громадського ладу; малоосвічений гімназист - i професор та автор грандіюзних наукових праць, яким не судилось, звичайно, побачити світ; українець, що з повагою та любов'ю ставиться до рідного краю - i виключно російський письменник, що жодного рядка рідною мовою (опріч одного приватного листа) не лишив у своїй літературній спадщині ${ }^{6}$. Вражає, що водночас цей мистець - цар сміху, хоча дуже важко уявити собі веселого Гоголя.

Микола Гоголь жив у якомусь вимірі магічного світу, у світі захоплення і розчарування. У нього було дивне прозріння тайни темних пристрастей. Загалом перед ним розкриваеться «мертвая бесчувственность жизни»: він починае зображувати зупинені, застиглі, непорушні обличчя - майже не обличчя, а маски. Письменник бачив світ під знаком смерті, sub specie mortis. Він відчував велике торжество, коли читав Біблію. Закріпити, зміцнити це почуття допомогло йому зна-

\footnotetext{
${ }^{5}$ Tам же.-C. 197.

${ }^{6}$ Єфремов С. Історія українського письменництва. - Нью-Йорк, 1911. - Т. 1. C. 359 .
} 
йомство 3 Адамом Міцкевичем, зі способом життя католиків у Римі, з книгами про різних святих. Микола Гоголь говорив: - «Бо в моій долі, як у всьому іншому, треба визнати участь Того, хто керуе цілим світом. Не так все стається, як цього нам хочеться - 3 Ним людині важко і навіть неможливо змагатися» ${ }^{7}$.

Усе свое бездомне життя письменник провів у дорозі, завжди бачачи перед собою обличчя смерті, як і його герої. Хіба не смерть змушуе Чічікова квапитись, хіба не вона жене його «російськими дорогами», хіба не від неї, як від перетинаючої його шлях похоронної процесії у 1-му томі «Мертвих душ», він тікае? Саме життя уявляється Гоголеві в образі дороги: вона починаеться народженням і впадає у смерть, як річка в море. «Всі зійдемося на тій самій дорозі, 一 пише Гоголь, - а дорога ця занадто лежить в основі нашого життя, занадто $є$ широка і помітна, щоб не потрапити на неї. Наприкінці цієї дороги - Бог, а Бог $€$ правда, а правда тим і глибока, що вона однаково всім зрозуміла - i наймудрішому, i дитині ${ }^{8}$.

Цей образ, що так просто розгортає перед нами глибоку перспективу, варто поставити поруч із класичним, що приписувано Піфагору. Життя подібне до театру: одні до нього йдуть взяти участь у грі, інші-крамарювати, а кращі - спостерігати. Так само і в житті звичайні люди женуться за славою і грішми, а філософи - за правдою.

Але як саме філософи ідуть за правдою, це залежить, у великій мірі, від природи людини, але, разом $з$ тим, і від народу, серед якого вона зростала. Шлях Гоголя за правдою - це заглиблення у себе, в свою душу, бо через неї лежить шлях до світу. Справжню правду можна осягнути, на думку письменника, лише душею, бо людина доходить до неї через переживання людей і подій «глибиною душі між сльозами, а не щоденними турботами» ${ }^{9}$. Людині дається світ у правді

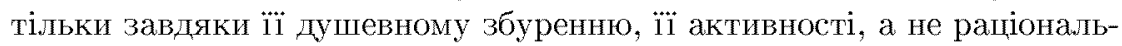
ному пізнанню. «Рухає душу порив і натхнення, - пише в одному 3 листів Гоголь, - натхненням багато чого схоплюеться, чого не дійдеш ніяким вченням і працею. Ось вам та правда, яку я завжди чув у душі, звідки виходять у нас всі правди, і яку стверджують щохвилі й власний та чужий досвід» ${ }^{10}$. За кілька років до смерті Гоголь писав А. Смирновій: «Я певен, коли закінчу свое служіння і завершу те, на

\footnotetext{
${ }^{7}$ Pязанов В. Легенда о великом пнквизиторе // Труды Киевской туховной академши, 1902.

8 Даижевич Н. Письма Гоголя в издании Пенрока. - СПБ, 1904.

${ }^{9}$ Tам дес

${ }^{10}$ Шенрож B. Материалы для биографии Гоголя. - Москва, 1892-1898. - T.I TV.
} 
що я покликаний, я помру» ${ }^{11}$. Гоголь був покликаний у світ, за його внутрішнім переконанням, не стільки показати Русь «з усіх боків» (що само по собі було колосальним завданням), скільки «засвітити світові», як він висловлюеться. Саме в цьому й полягає, вважав письменник, ота найбільша користь, яку він здатний дати. Питання про світло - корінне питання для Гоголя. Воно йде від Шеллінга (розуміння світла як розуму) і характерне для української філософії XIX століття, зокрема для Памфіла Юркевича (безпосереднього вчителя Володимира Соловйова). «Засвітити світові» Значило для мистця-мислителя привносити у життя суспільства лад і гармонію, навертати на добро. А в який спосіб це зробити, він ніколи не переставав розмірковувати. Напрямок пошуків був обумовлений і опосередкований тими уявленнями про суспільство, які Гоголь поділяв. Для його соціальних уявлень характерна абсолютизація ролі соціально-психологічних факторів і процесів. Можливості зміни соціальної ситуації в державі Гоголь пов'язував зі зміною звичаїв; зміни ж звичаїв, за його думкою, можна досягнути тільки шляхом вдосконалення кожної окремої людини, зокрема очищенням ї̈ душі, як і власної теж. Так, другий том «Мертвих душ» пронизуе думка про суспільне благо. Основною категорією суспільного блага $є$ служба. I очолювати цю службу повинен цар любові або теократичний цар. «А в моїй долі, писав Гоголь, - вирішальну роль відіграє той, хто керуе цілим світом. Створив мене Бог і не утаїв від мене призначення мого. Народився я зовсім не для того, щоб створити епоху на полі літературному. Діло моє простіше і ближче: діло моє, про яке перед усім має думати кожна людина, не лише я. Діло мое - душа і тривке діло жити» ${ }^{12}$.

Розуміючи творчість як «чисту сповідь душі, дар Божий, а не породження мистецтва чи бажання людського», як «правду душі», Гоголь став засновником моралізуючого напрямку в нашому мистецтві та першим представником моралізуючої публіцистики, а його послідовниками - Достоєвський, Гліб Успенський, Лев Толстой, Булгаков, Пастернак.

Мислитель уявляв душу як таку, що має три ступені досконалості. Найнижча ступінь - «мертві душі», «душі чорні». «Мертва душа»це душа, що зупинилась у своєму розвитку, аморальна та огидна у своїй порожнечі. У мертвій душі нема Божої іскри - прагнення до правди; нема свідомості-сама фізіологія; нема любові ні до людини, ні

${ }^{11}$ Гоголь Н.В. Собрание сочинений: В 4-х томах. - Москва, 1968.- Т. 4.- С. 296.

12 Житецьжий И. Гоголь - проповедник и писатель.-СПБ, 1909. 
справи, ні до батьківщини; її совість зовсім маленька, а замість неїстрах. Уважно досліджуе Гоголь «чорноту душевну». Це тема «Страшної помсти», «Вія», «Записок божевільного», «Портрета», «Мертвих душ». Згадаймо, як у «Травневій ночі» літературний персонаж Левко, розшукуючи серед русалок відьму, безпомилково їі знаходить: «Тіло іï не так світилося, як в інших, в середині виднілося щось чорне». «Страшна душевна чорнота!», - вигукуе Гоголь у «Заповіті».

Друга ступінь - душі «пропащі». 3 хорошими задатками і здібностями, вони поступово дрібнішають внаслідок моральної розпусти. Гоголь зустрічав їх «у всіх званнях і станах»: ситні, пияки, телепні, тюхтії, скиглії, гризуни, базіки тощо. Зображуючи типи цієї категорії, наприклад, шевця Максима Телятникова, Хлобуева чи братів Платонових, Гоголь частіше, ніж будь-коли, розмірковував про основні властивості російської душі й описав тип найбільш національний. «Дійсно, за словами Дмитра Овсянико-Куліковського, - безвольність, лінь, відсутність витримки, недостача енергії і працездатності споглядаються частіше в російській масі, навіть і в інтелігенції. Але Гоголь, із властивою його натурі здатністю перебільшувати, надавав цій нашій ваді аж надто великого значення і підносив її до ступеня однієї із основних рис нашої національної психології без необхідних у такому випадку обмежень та застережень» ${ }^{13}$.

$\mathrm{I}$, врешті, найвища ступінь - це ідеальна людина. Вона представлена позитивним українським характером епічного (за Гоголем) стану світу, зокрема в «оповідках» про героїчне життя молодого («младенствующего») народу, яскравими представниками якого стали Тарас Бульба і Данило Бурульбаш, Остап Кукубенко і Мусій Шило. Це також «живі душі» парубків і дівчат українського села.

Як некрасу людської душі Гоголь побачив у їі мертвості, так і навпаки - за ідеал він вважав жкиву душу. Знову не інтелект, не волю він ставить на чільне місџе, а чуття, емоцію, здатність глибоко і жваво реагувати на життя. Жива душа-це прекрасна душа, а емоційний елемент - їі обов'язкова властивість. Тому люди й народи, що визначаються своїм емоційним характером, користуються в Гоголя такою симпатією: «Вишневі низенькі садки і соняшники понад тинами, і солом'яна стріха чисто вимазаної хати, i мале з червоним обводом навкруги віконце. Ти-старовинний корінь Русі, де сердечніше чуття i ніжніша слов'янська природа» ${ }^{14}$.

${ }^{13}$ Овсянико-Куликовскій Д. Гоголь // Собрание сочиненій. - Т. 1. - СПБ, 1909.

${ }^{14}$ Гоголь Н.В. Собрание сочинений: В 4-х томах. - Москва, 1968. - Т. 4. - С. 26. 
Впродовж усього свого життя мистець-мислитель шукав шлях, на якому кожна людина може «вибілитись», позбутись внутрішніх суперечностей, знайти душевну рівновагу з оточуючим світом.

Пошуки такого шляху були органічно пов'язані з еволюцією світогляду Гоголя і пройшли декілька етапів, але на кожному з них чільне місце у вихованні займають труд, праця. їм мислитель надає надзвичайно великого значення у формуванні справжньої людини. «Тільки один здобутий нами корисний труд є джерелом душевної радості, тривкого становища у світі, непорушного душевного спокою, ясного погляду на світ, світлого потягу до Бога» ${ }^{15} .3$ цієї точки зору Гоголь цінував доброго господаря і добре господарство. «Для чого потрібне господарство? - писав він. - Бо від нього залежить добробут усієї держави, бо складається краще життя окремої людини, бо робота і безупинний рух зміцнюють тіло і здоров'я, бо від цього самі розумові здатності є свіжі, бо, нарешті, в цьому виконуе людина свій обов'язок і призначення, дане од Бога працею здобувати хліб» ${ }^{16}$. Життя кожної людини теж повинно бути добре впорядкованим господарством. Таке господарство Гоголь розуміє як працю і творчість для Вічного.

Схематично можна виокремити три етапи гоголівських пошуків шляху морального вдосконалення людини.

На першому етапі (1829-1845 pр.) Гоголь виступае як романтик, i для його світогляду характерне властиве для романтизму усвідомлення різкої межі між ворожою людині дійсністю та утопічним світом мрії, втіленим у мистецтво. Мистецтво, зокрема музика, було для Гоголя як останній притулок духовності. У статті «Скульптура, живопис і музика» він писав: «О, будь же нашим охоронцем, рятівником, музико! Не залишай нас! Пробуджуй частіше наші меркантильні душі! Вдаряй різкіше своїми звуками по дрімаючих наших почуттях! Якшо й музика нас залишить, що буде тоді з нашим світом?» ${ }^{17}$ На першому романтичному етапі еволюції своїх поглядів Гоголь вважає, що людина досягає гармонії сама з собою в ілюзорному світі, створеному засобами мистещтва.

На другому етапі (хронологічні рамки якого можна приблизно обмежити кінцем 1835 - початком 1842 років) Гоголь дійшов думки, що для того, щоб людина бажала виправитись, вона повинна усвідомити необхідність цього. Усвідомленню необхідності зміни сприяе, за Гоголем, зображення «порядків, які у всіх щоденно перед очима». Виявле-

\footnotetext{
15 TaM aнe.

16 Tam же.

${ }^{17}$ Taм же - С. 15.
} 
ння та зображення за допомогою «ллузвання, і правди, і карикатури» наявного зла «багатьох зачепило за живе», сприяючи тим самим самопізнанню та самосвідомості російської нації. Почуття зла в Гоголя було надзвичайне за своєю силою. Він сам жахався цього в собі, але саме те, що було власною духовною якістю письменника, й породило всю гостроту його художнього зла. Він один із тих перших письменників, що художньо передали почуття якихось темних, злих, містичних сил, які приховуе в собі дійсність. Гоголь перший у літературі показав, що в задзеркальному світі існують деякі речі, в реальності не виявлені: їх можна описати лише як звуки, голоси чи фігури потойбічного світу.

Дивна й незвичайна творчість Гоголя не може бути віднесена тільки до розряду суспільної сатири, що викриває тимчасові й минущі пороки та гріхи суспільства дореформеної Російської імперії. Художні прийоми Гоголя є своєрідним експериментом, який розчленовує і розплітає органічно цілісно дійсність, розкриває щось надзвичайно істотне для Росії, якісь духовні хвороби, не виліковані ніякими суспільними реформами та революціями, хвороби, які так само роз'єднають і нашу сучасність. Важко не побачити правду в словах Бердяєва: «Нема вже старого самодержавства, а на Русі, як і раніше, нема поваги до людини, до людської гідності, до людських прав. Нема вже старого чиновництва, старої поліції, а хабар, як і раніше, $е$ підвалинами російського життя його «конституцією». Відбувається грандіозна нажива на революціï. Сцени з Гоголя розігруються на кожному кроці в революційній Росії» ${ }^{18}$.

Третій етап гоголівських пошуків шляху морального вдосконалення людини (що охопив останне десятиріччя його життя: 1842-1847рр.) знайшов своє відображення, перш за все, в книзі публіцистики «Вибрані місця із листування 3 друзями» (1847р.). Прочитайте 11і зараз і побачите, як мислитель передбачив багато «страхіть і жахів» Росії, які ïi струсонули у XX столітті. Одна з головних тез книги полягає в тому, що не революціями і не руйнуваннями перетворюеться суспільство, не зміною зовнішніх обставин, а змінами у внутрішньому світі людини. Книга починае пророчу суперечку, в якій чітко позначаються два погляди на прогрес, на шляхи розвитку Росії в XX столітті. Вона, книга, випереджує суперечки Достоєвського і Лескова з нігілістами. Толстого - 3 революціонерами. Тут на одній позиції - бомбометальники і прихильники зміни основ суспільства за допомогою сили, на другій філософи самовдосконалення, вороги крові, вороги насильства.

${ }^{18}$ Бердлев М. Смысл истории.-- Париж, 1923.-С. 17. 
У світоглядному плані погляди Гоголя цього періоду є виразом комплексу ідей, що умовно об'єднуються назвою «Москва - третій Рим». Думки про особливу історичну місію Росії, про багатообраність російського народу мали давню історичну традицію і посилились саме в першій половині XIX століття. У цей час Гоголь дещо відходить від проблем України, тому й не дивно, що таку поведінку суворо засудили Євген Маланюк, Сергій Єфремов, Борис Грінченко. Сергій Єфремов, наприклад, пише: «Українці типу Гоголя по дві носили душі в грудях і хитаючись між тими двома душами, часто не знали, котрої слухатись, i ніяк не могли напевне вибрати, на яку їм ступити щодо України, їі народу та його національного життя» 19 .

Тонка натура Гоголя передбачала таку критику. Він дає відповідь своїм опонентам: «Не ламав я собі голови, коли мав якісь сумніви, а махнувши рукою ішов дальше і справді Бог мені допомагав, і все з'ясовувалось само собою. Тому просіть у Бога, щоб Він вогнем благодати спопелив у вас холодну черствість, на яку тепер страждають найліпші і найкращі люди. Будьте не мертві, а живі душі. Нема інших дверей, як ті, які вказував Христос, і хто ходить іншими - $\boldsymbol{\varepsilon}$ злочинець» ${ }^{20}$.

Говорячи тепер про необхідність світла для душі, Гоголь чітко розрізняе поняття освіти і просвітлення. Освіта збагачуе розум народу знаннями, але, щоб наука збагатила ще й душу, потрібна вища ідея. Цією ідеєю Гоголь вважав християнську ідею. Він і на мистецтво дивився як на «незриму ступінь християнства». Не зрозумівши цього, ми не розуміємо Гоголя, не зрозуміємо ані його життя, ані закінчення цього життя.

Для Гоголя Ісус Христос-це Вчитель і Спаситель, вершина його мудрості-закон, проголошений у Загірній проповіді, а вищий приклад - страждання і загибель на хресті за гріхи людей і їхнє спасіння. Воскресіння несе для людства «благую вість» не про продовження нудної безконечності земного Снування - цього було б замало - а Рятувальне відродження душі. Найвищою цінністю для Гоголя неминуча мудрість ідеї любові до ближнього, яку проголосив Христос, та їі відкуплюючий і миротворчий сенс. У християнстві Гоголь вбачав єдину і надійну моральну опору в цьому світі, який немов просякнений взаємним непорозумінням та божевіллям.

Невтомно прислухаючись до «вказівок» 3 неба, Гоголь виробив для

\footnotetext{
${ }^{19}$ Ебремое C. Історія украйнського письменництва. - Нью-Йорк. 1911. - Т. 1. C. 398 .

${ }^{20}$ Цит. за: Бучинський Д. Християнсько-філософська думка Т.Г. Шевченка. Мадрід-Лондон, 1962.-С.213.
} 
себе «теорію пізнання» шляхів Провидіння i, одночасно, теорію чудодійної сили молитви. У Гоголя була специфічна теорія молитви. Він, наприклад, в 1843 році писав Язикову: «Молитва не є словесна справа, вона повинна бути від усіх сил душі, без того вона не очистить. Молитва - це захоплення. Якщо вона дійшла до ступеня захвату, то вона прохає про те, чого Бог бажає, а не про те, чого ми хочемо» ${ }^{21}$. Така теорія молитви говорить про дуже складний релігійний світогляд Гоголя: для нього, як християнина і філософа, дороговказом є думка про те, що «тяжко буде покараний той, хто дістав від Бога талант і закопав його в землю. А немає людини, щоб не дістала якого-небудь таланту. Я гадаю, що всі ми - наймити на світі. Ми повинні сумлінно працювати, використовувати ті здібності, які нам дав Бог, не чекаючи зарплати тут, а там» ${ }^{22}$.

Мислитель певен, що християнство вимагає, перш за все, кликати людей до правди особистим прикладом. Крім того Гоголь не вмів писати «повз себе», тобто сам не підносячись до тієї висоти, до якої він хотів би піднести читача. Однак його душа чим далі, тим більше катувала себе повною відсутністю гармонії.

Влітку 1859 року, відвідуючи Оптину Пустинь, Гоголь ділиться своїми сумнівами з ієромонахом монастиря і пише про себе: «Я найгірший та найнегідніший 3 усіх». Він просить молитись за нього, бо Христос «в силі, милосердний, зробити все: і мене, чорного як вугілля, вибілити і піднести до тієї чистоти, якої повинен досягнути письменник, що наважився говорити про святе і прекрасне» ${ }^{23}$. Проте незадоволення собою, своїми пошуками все наростае. Щодо власної творчості Гоголь приходить до висновку: «Все нікуди не годиться і все треба переробляти».

Філософія Гоголя є іманентно-поетична. Вона не акцентуеться спеціально, а немов розлита в художніх та публіцистичних творах. Все життя Гоголь «йшов з правдою». У центрі його уваги - душа людини, і вся його творчість - «душевна правда», мета якої - вказати людині шлях до Бога, просвітити християнською ідеєю, любов'ю і милосердям. Гоголь дав поштовх духовним пошукам релігійно-філософської думки. Його проблеми поставали перед Федором Достоєвським, Львом Толстим, Володимиром Соловйовим, Миколою Бердяєвим, Олександром Кульчицьким, Дмитром Чижевським та іншими філософами. Водночас і справдилися його слова: «Знаю, що моє ім'я після мене буде

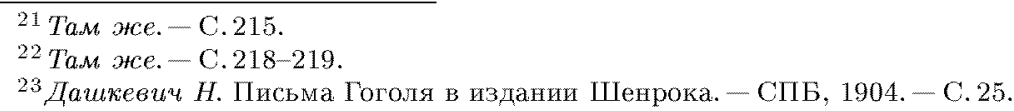


щасливіше за мене, й нащадки тих же земляків моїх, може з очима вогкими від сліз, бажатимуть миру моїй тіні» 24 .

Важливо зрозуміти суть «душі» у Гоголя. На його думку, заглиблюючись у себе, вона виробляе свое внутрішне око і може пізнати те, чого не осягне та людина, яка живе матеріальним життям, бо «просвітити - не значить повчити, чи наставити, зробити освіченим, але висвітлити наскрізь усю людину, в усіх ï силах, не лише їі розумові пронести всю її природу крізь якийсь огонь, що очищуе. [...] Забув навіть, що ум іде вперед, коли ідуть усі моральні сили людини, стоїть без руху, навіть іде назад, коли не поступають моральні сили» ${ }^{25}$. Отож «виховуючись для світу не серед світу, але віддалік від нього заглиблюючись в самих себе й досліджуючи усю душу свою, бо там закони усього й усьому. Знайди лише ключ до своєї власної душі; коли ж найдеш, тоді тим самим ключем одімкнеш душі усіх ${ }^{26}$.

Звідси й всі вирази, що так «густо розсипані в листах Гоголя: душевна справа, душевна робота, душевний порух, душевний поцілунок, душевні обійми, душевна участь, душевна молитва, душевна сповідь, душевна тайна, душевна віра, душевні надії, внутрішній голос, внутрішній суддя, стан серця, велике свято для душі, душевний рік, засміятися сміхом душі і т. ін.» 27 .

Ключ до світу Гоголь знайшов у власній душі, де його знаходили великі філософи: Сократ, «демон» якого так подібний на внутрішній голос Гоголя; Платон, душа якого згадувала про виший світ містики; Декарт... Але «ключі», що вони знайшли, виявляють певні відміни. Тоді як Платон знаходить найпевніше саме в ідеї, думці, Декарт-у свідомості, у Гоголя ж бачимо ми душевну емоцію, серце (як у Сковороди і Юркевича).

«Рухає душу порив і натхнення, а натхненням багато дечого схоплюється, чого не дійдеш ніяким вченням і працею. Ось вам та правда, яку я завжди чув у душі, звідки виходять у нас всі правди, і яку стверджували мені щохвилі і власний, і чужий досвід» ${ }^{28}$. Відчуваючи гармонію в собі, душа вразлива на гармонію навколо неї. Ми бачили, яка саме властивість особливо проявляється у подорожніх Гоголя -

\footnotetext{
${ }^{24}$ Бучинсъжй Д. Християнсько-філософська думка Т.Г. Шевченка.-МадрідЛондон, 1962.- С. 219

${ }^{25}$ Там. же.

${ }^{26}$ Там жес.

27 Tам же.

${ }^{28}$ Див.: Чижевсьжий Д. Нариси 3 історії філософії на Україні.-Нью-Йорк, 1991. - C. 87-106.
} 
відчуття втіхи з прекрасного.

На першому етапі своїх поглядів Гоголь вважав, що мистецтво є, в повному розумінні, порятунком від реальної дійсності для тих, хто не зумів задаптуватися до «меркатильного століття». Такий погляд багато в чому був наперед визначений уявленнями про незмінність характеру людини, які існували у той час у Гоголя. Він різко протиставляв «синів істотності жалюгідної» й «небокоптителів»-i тих, хто дійсно заслуговуе на право зватися людиною. 3 роками його статичні уявлення про характер людей змінилися на динамічні. А важливий засіб перетворення «існувателя» в особистість Гоголь побачив у мистецтві.

На другому етапі світоглядних змін гоголівський пошук форм $\mathrm{i}$ шляхів впливу на дійсність, адекватно його творчим потребам, знайшов свою концептуальну об'єктивізацію в теорії суспільної комедії (а художне втілення - в п'єсах Гоголя). Класицизькій зневазі комедією, як низьким жанром, романтичному змішуванню жанрів Гоголь протиставляє реабілітацію комедій. За його думкою, комедія на цей час неначе заступила місце трагедії.

Гоголівське уявлення про жанри пов'язане з усвідомленням особливої ролі сміху. У своїх статтях мислитель розрізняе чотири різновиди сміху. Перший - «сміх, який породжуеться легкими враженнями, побіжним дотепом, каламбуром», «легкий сміх, що служить для Дозвільної розваги і забави людей». Другий - «сміх, який рухає грубим натовпом суспільства, для якого потрібні конвульсії та карикатурні гримаси природи». Третій-«сміх, який породжується тимчасовою дратівливістю, жовчним, хворобливим характером». I, нарешті, четвертий «той, електричний, живодайний сміх, який вихоплюеться мимохіть, вільно і не очікувано, прямо від душі, захопленої сліпучим блиском розуму, народжуеться зі спокійної насолоди і виробляться тільки високим розумом», який увесь вилітає з світлої природи людини, вилітає з неї тому, що на дні її вічно б'е джерело її, що поглиблюе предмет, змушуе яскраво виступити те, що прослизнуло б, без проникливої сили якого дріб'язок і порожнеча життя не перелякали б так людину» ${ }^{29}$. Важливість, цінність того чи іншого різновиду сміху визначаються його виховними можливостями. 3 цієї точки зору едино важливим і заслуговуючим на увагу $\epsilon$ четвертий із цих різновидів, який виокремив письменник.

Гоголь робить наголос на моральний струс, який пережив кожний глядач під час спектаклю, і подалыше духовне очищення, яке відбулося

${ }^{29}$ Taм же. 
завдяки џьому сміху. Не застосовуючи самого слова «катарсис», він, фактично, покладає надії на катарсичний вплив комедії. Сутність змін у поглядах третього етапу одержала вираз у концепції «мистецтвоце примирення 3 життям».

Безсумнівно, Гоголя приваблювали психопрофілактичні можливості мистецтва. Це стримування «елея всепрощаючої любові до брата», яке він так гостро відчував, ця своєрідна емоційна розрядка, яку одержує реціпієнт мистецтва при його сприйнятті, наближує в його очах катарсичний вплив мистецтва до ролі сповіді християнина своєму духівникові.

Виразом поглядів на мистецтво е повість «Портрет», де яскраво виставлена безглуздість вимог, які натовп часто адресуе мистцеві. Художник стає модним, коли починає лестити смакам натовпу, тобто забувае про правду зображення. Однак дешева популярність нищить художника: проникнення в суть речей підмінюе в нього вправність й жвавість пензля. Він зрадив той заповіт, який старий художник дав своєму синові: «Вивчай все, що не побачив, підкори усе пензлеві, у всьому вмій знаходити внутрішню думку. I найбільше прагни проникнути у високу таємницю. Щасливий той обранець, що володіє нею. Нема йому низького предмету в природі. В ницому художник та кий само великий, як і у великому, в жалюгідному для нього вже нема зневаги, бо просвічує невидимо крізь нього прекрасна душа Того, хто створив, і жалюгідне вже одержало високий вираз, бо протекло крізь чистилище його душі... Натяк на божественний небесний рай ховається для людини в мистецтві, і через це єдине воно вже вище за все» ${ }^{30}$.

3 врахуванням вищезгаданого стають доступнішими уявлення Гоголя про завдання мистецтва під час третього етапу еволюції його поглядів: «Мистецтво е внесення в душу стрункості і порядку, а не баламучення й розбрату. Мистецтво повинно змальовувати нам таким чином людей землі нашої, щоб кожен з нас відчув, що це живі люди, створені й взяті з того ж тіла, з якого й ми. Мистецтво повинно виставити нам на вид усі доблесні народні наші якості й властивості, не виключаючи навіть тих, які, не маючи простору вільно розвиватися, не усіма помічені та оцінені так вірно, щоб кожен відчув у собі самому те, що ним закинуто й забути. Мистецтво повинно виставити нам усі погані наші якості та властивості таким чином, щоб сліди їх кожен 3 нас відшукав, перш за все, в собі самому і подумав би про те, як 3 початку з самого себе скинути все, що потьмарює шляхетність нашої

${ }^{30}$ Taм же. 
природи. Тоді тільки, і таким чином діючи, мистещтво виконае свое призначення та внесе порядок і стрункість в суспільство» ${ }^{31}$.

Гоголівська концепція призначення мистецтва мае певну внутрішню логіку. Настав час усвідомити, що мислитель шукав істину на шляхах, які історично себе виправдовують. Цінним є те, що Гоголь прагнув не просто вказати якийсь абстрактний плях вдосконалення особи, але, пізнавши його, хотів пройти ним спочатку сам, а потім зробити його доступним для всіх, взявши за основу силу впливу художніх образів.

Таким чином, все життя Гоголя переслідуе примара відплати, примара покарання за гріхи, за вину. Це одна із головних тем його творчості. Який би твір Гоголя ми не взяли, там є гріхи, суд і покарання, є викриття, каяття і сльози.

Покарання чекає на городничого в «Ревізорі» і на Чічікова в «Мертвих душах». Відплата нависла над головою бідного Піскарьова 3 «Невського проспекту» $\mathrm{i}$ Черткова 3 «Портрету». Грім покарання вибухає над Ковальовим в «Носі» та над «значною особою» в «Шинелі». Особливо страшна кара чекае на зрадників: чаклуна в «Страшній помсті», Андрія в «Тарасі Бульбі», Петруся в «Ночі напередодні Івана Купала». Особливим гріхом вважає Гоголь і зраду тих, хто відмовляється від національної приналежності. Таких він вбивае влучним і безпощадним словом. Симпатичних Гоголеві старосвітських поміщиків він протиставляє «тим ницим малоросіянам, які видираються 3 дегтярів, гендлярів, наповнюють, як сарана, палати канцелярії, деруть останню копійку в своїх таки земляків, наповнюють Петербург крутіями, наживають, нарешті, капітал і урочисто додають до свого прізвища, що закінчується на „,", літеру „в". [...] Hi, - закінчує Гоголь про своїх героїв, - вони не були схожі на ці огидні та жалюгідні створіння, так само, як і всі малоросійські корінні фамілії ${ }^{32}$.

Гріх, вина у Гоголя карається публічним висміянням, крахом i смертю. Але, як правило, людина сама усвідомлює жах своїх діянь і готова предстати перед судом. Суд у Гоголя різний, але внутрішній суд-найстрашніший. Перед його обличчям бліднуть вироки уряду громадської думки та публічної критики, перед ним поступається навіть нечиста сила. Не Вій вбиває Хому Брута, а острах Хоми, що він переступив межу.

I сам Гоголь у лютому 1852 року вирішив, що «закінчив свое слу-

\footnotetext{
31 Taм же.

32 Даикевич Н. Письма Гоголя в издании Шенрока.-СПБ, 1904.-С. 284.
} 
жіння і завершив», і прирік себе на смерть.

Доктор Тарасенков, що лікував Гоголя в останні дні його життя, свідчить про тверду волю Гоголя. Всі прохання прийняти їжу не діяли на нього (він відмовлявся їсти й пив тільки воду 3 вином), від насильного лікування він теж відмовився. Гоголь на все відповідав: «Облиште мене». «Він дивився як людина, - пише Тарасенков, - для якої всі задачі розв'язані, всяке почуття замовкло, всякі слова марні, коливання в рішенні вже неможливі ${ }^{33}$.

Гоголь помер у 43 роки, забравши в могилу ключі від своєі таємниці; помер, не залишивши після себе нічого, крім портфеля з паперами й того обличчя «мученика високої думки» (слова Сергія Аксакова), яке запало в пам'ять сучасникам. За пією трагічною смертю слідувала легенда про летаргічний сон; про те, що під час ексгумації Гоголя знайшли повернутим у труні.

Українська критика дає свое тлумачення трагедії письменника. «Сказу вам, - писав Гоголь до Смирнової, - що я сам не знаю, яка в мене душа: хохляцька чи російська. Знаю тільки, що ніяк не віддав би переваги ані малоросіянину перед росіянином, ані росіянину перед малоросіянином. Обидві природи щедро обдаровані Богом, i, як навмисне, кожна 3 них окремо містить в собі те, чого нема в іншій» 34 .

Важко було Гоголеві у повсякденному житті, і складно було оцінити його спосіб життя. Навіть такі знавці людських душ як Борис Грінченко теж не змогли зрозуміти внутрішній світ Гоголя ${ }^{35}$.

Ця людина, для якої найбільш важливим у світі була «справа душі», заплуталась таки у власній душі. I саме це стало початком її власної драми; те маленьке зерно що 3 нього виросла потім велика трагедія всього їі життя, виявившись такою силою суперечностей i контрастів, що їх тягаря не міг витримати на собі нещасний письменник.

3 цього виросла і така суперечність: Гоголь своїми творами з українського жкитя гартував українську свідомість одних, а водночас дав аргумент проти тієі свідомості другим, бо геніальний українець, що став проводирем не свого рідного, а «сусідського» письменництва, чи не найкраще ж ілюструе думку, що весь кількавіковий рух України до державності ні на що і нікому не потрібний, i тим самим шкідливий.

Ця вищезгадана суперечність коріниться в тому нещасливому і глибоко трагічному «сам не знаю». Бо коли Сократ правило «пізнай себе»

\footnotetext{
33 Taм жсе.

34 Tam же. - C. 285

${ }^{35}$ Гріниенжо Б. Листи з Украӥни Наддніпрянської.- Відень, 1909. - С. 47-48.
} 
поставив за мету і зміст цілого людського життя, то можна уявити, що почуває не звичайна, пересічна, а велика людина, коли вона сама не знає, хто вона є; яка трагедія відбувається на грунті цього незнання елементарно потрібного для щастя і морального задоволення для душі.

У Гоголя, безперечно, було дві «душі», вважає Сергій Єфремов, українська і російська ${ }^{36}$. Одна - молода, свіжа, поетична, овіяна мріями про далекий і милий серцю рідний край; друга - стареча, холодна, сувора, з службовими намірами та зі звеличенням офіційної російської держави. I кожна душа жила в ньому власним життям, кожна вимагала для однієї себе повної неподільної уваги, кожна домагалася собі Одній цілої істоти письменника, кожна тягла його виключно у свій бік. Духовна сутність нещасного письменника була в самому корені надломана й переповнена.

Микола Гоголь став жертвою своеї національної невизначеності. Щоб урятувати себе і свій талант від завчасної погибелі, щоб знайти спокій собі та добрі обставини для праці, йому конче треба було «дати перевагу» якійсь одній душі: або твердо й безкомпромісно лишитись на українському грунті, як це зробив, наприклад, Іван Котляревський, або так само твердо й безоглядно ввійти у російське життя і письменництво, як це зробили його ж земляки-полтавчани Іпполіт Богданович, Василь Капніст, Василь Наріжний, Микола Гнідич і як досі це роблять російські письменники українського походження.

Або - або, третього виходу не було, бо третім і була саме та дводушність, що немов розділила Гоголя на дві половини, напоїла його прагнучу добра істоту напоєм вічних вагань і хитань та передчасно довела його до смерті, завдавши йому спочатку стільки муки, що проста людина не здатна їі витримати.

Але, при всьому тому, противником України Гоголь не був і, певна річ, не міг бути, бо на це не поступила б його «хохляцька душа». Гоголь виріс з українського грунту, на ньому грунтувалися всі умови його виховання і життя - виховання панича і життя серед інтересів, чужих рідному краєві, але його українська душа довго боролася проти цього, виявляючись несвідомо для самого автора в кращих творах його таланту. Микола Гоголь мало того, що писав про українські проблеми, а ще виявив краще, ніж хто другий, одну із основних прикмет нашого національного характеру - гумор (незважаючи на складність нашої історії). Через Це Гоголь нам двічі рідний i, напевне, залиши-

36 Див. вище. 
ться таким навіки, скільки б не розвивалася українська літературна спадщина.

Тарас Шевченко, маючи апостольський дар провидіння, у листі до княгині Репіної писав: «Наш Гоголь - справжній знавець людської душі! Тому навіть самий визначний поет повинен благоговіти перед ним, як перед людинолюбцем» ${ }^{37}$. Ми вважаємо, що кожний свідомий українець теж перебуватиме у стані такої душі, коли детальніше ознайомиться зі спадшиною Миколи Гоголя. Це дуже дивно, бо, на перший погляд, повне зібрання його творів ще й досі не видано. Отож вже назріла нагальна потреба опрацювати, видати і ознайомити українців 3 усією спадщиною славетного сина України - Миколи Гоголя.

${ }^{37}$ Шевченко Т. Твори: У 5 -ти томах. - Т. 5 . - К.: Видавництво художньої літератури, 1979.- С. 277 . 